\title{
AĐ GANGA INN Í VERÖLD ANNARRA ER ÖGRUN: LEIĐIR AĐ HUGMYNDUM KENNARA UM STARF SITT
}

Á síđari hluta 20. aldar komu fram kenningar og ađferđir í kennararannsóknum sem endurspegluðu nýja hugmyndafræđi sem ætlað var að dýpka skilning á kennarastarfinu. Samkvæmt pessum kenningum er mikilvægt að öðlast dýpri skilning á hugmyndum kennaranna sjálfra og gefa peim rödd til að efla pá í starfi og próa skilvirka símenntun. Lađa parf fram hugmyndir kennarans um starfið og gildin sem að baki liggja. Samkvæmt pessari rannsóknarhefð er ekki rætt um rannsóknir á kennurum heldur rannsóknir í samvinnu við kennara. Markmið greinarinnar er að vekja athygli á slíkum ađferđum. Í pví skyni eru gefin dæmi um leiðir sem reynst hafa vel til að fá fram hugmyndir kennara og viðhorf til starfsins (starfskenningu). Lífssaga kennara er talin góð leið til að komast að kjarna starfskenningar hans. Tekið verður dæmi af lífssögu eins kennara og saga hans rakin. Siðferðileg álitamál í tengslum við slíkar aðferðir verða einnig rædd.

Efnisorđ: kennararannsóknir, lífssögurannsóknir, próun starfskenningar

Taliđ er að skilningur á pví hvernig kennari hugsar um starf sitt, starfar og proskast faglega á kennsluferlinu geti gefið nýja sýn á skólastarf og leitt til umbóta á pví. (Sigrún Ađalbjarnardóttir, 2007, bls. 253-254)

\section{INNGANGUR}

Kennarastarfið var lengi vel lítið rannsakað og pað var ekki fyrr en eftir miðja síđustu öld að pað kom veruleg hreyfing á kennararannsóknir. Í byrjun beindust rannsóknirnar að pví að finna með mælingum tengslin milli pess sem kennarar gerđu í kennslustofunni og pess sem nemendur lærđu. Á síđari hluta 20. aldar komu fram kenningar og nálganir sem endurspegluðu annars konar hugmyndafræđi (Goodson, 1992a; Pope og Denicolo, 2001). pekkingarfræđilegur grunnur peirra liggur í kenningum hugsmíđahyggjunnar. Samkvæmt peim parf að öđlast dýpri skilning á hugmyndum kennaranna sjálfra og gefa peim rödd til að efla pá í starfi og próa skilvirka símenntun. Lykillinn er að hlusta á kennara og fá fram hugmyndir peirra um starfið en ekki síst gildin sem að baki liggja (Elbaz, 1990; Goodson, 
1992a). Ljóst mátti vera að pótt eldri ađferđir gæfu ýmsar upplýsingar um kennarastarfið pyrfti nýja nálgun til að komast að hugsun kennaranna sjálfra um hið margbreytilega starf. Í pessu skyni hafa ýmsar leiđir og ađferđir verið próađar undanfarna áratugi.

Samkvæmt pessari hugmyndafræđi er ekki rætt um rannsóknir á kennurum heldur rannsóknir í samvinnu við kennara; ekki er litið á kennara sem rannsóknarviðföng heldur sem samverkamenn í leit að auknum og nýjum skilningi. Meginmarkmið pessarar greinar er að vekja athygli á slíkum aðferðum og gefa dæmi um leiðir sem reynst hafa vel við að fá kennara til að tjá hugmyndir sínar og viðhorf. Til að komast enn nær kjarna hugmynda kennara og gildum peirra hefur einnig pótt æskilegt að fá fram hvað pað er í lífi kennara, umhverfi og starfi sem peir telja að hafi mótað pessar hugmyndir og gildi (Sigrún Aðalbjarnardóttir, 2007). Til að sjá hvernig pessar aðferđir reynast verður hér tekið dæmi af einum kennara og saga hans rakin.

\section{Í LJÓSI SÖGUNNAR}

Árið 1986 birti bandaríski prófessorinn Lee Shulman grein par sem hann bendir á að pótt kennsla sé međal elstu starfa séu kerfisbundnar athuganir á kennarastarfinu tiltölulega nýtt viđfangsefni. Á sjöunda og fyrri hluta áttunda áratugar síđustu aldar var töluverđ gróska í rannsóknum á kennurum. Mest fór fyrir skilvirknirannsóknum (e. processproduct research). Meginmarkmið peirra var að skoða tengslin milli athafna kennara og athafna nemenda, telja pær athafnir sem fyrir augu bar (e. observable behaviour) og mæla pannig skilvirkni kennarans. Pótt slíkar rannsóknarađferđir hafi verið gagnrýndar vegna pess hve skammt pær ná sýndu pær pó međal annars fram á að kennarinn skipti máli (Shulman, 1986).

Í framhaldinu vöknuðu nýjar spurningar um hvað pað væri í starfi kennarans sem skipti máli. Shulman (1987) setti fram eftirfarandi spurningar: Hver er uppspretta pekkingar kennarans? Hvađa pekkingu býr kennarinn yfir og hvað kann kennarinn og hvenær varð sú pekking til? Hvernig öđlast hann nýja pekkingu eđa rifjar upp eldri pekkingu og hvernig geta pessar tvær tegundir pekkingar myndađ nýjan, samfelldan pekkingargrunn? Um svipađ leyti var farið að líta á kennarann sem geranda (e. active agent) í eigin starfspróun (Calderhead, 1987). Rannsóknirnar höfðu pannig snúist frá pví að beinast að hegðun kennara til pess að reyna að skyggnast inn í hugsun peirra um starfið. Clark og Peterson (1986) töldu að pessa tegund rannsókna mætti greina sundur í prjá meginpræđi: a) rannsóknir sem beindust að undirbúningi og skipulagi kennslu, b) rannsóknir sem beindust að ákvörđunum kennara, pað er hvað byggi að baki ákvörđunum peirra, c) hugmyndir kennara um starf sitt, oft kallað starfskenningar. Í pessari grein er pessum síđasta præði fylgt.

Markmið rannsókna á hugmyndum kennara um starf sitt var að skilja betur hvernig kennarar proskuðust í starfi (Kagan, 1992). Leitast var við að skilja kennara á peirra eigin forsendum (Zeichner, Tabachnick og Densmore, 1987), kennarinn sem einstaklingur og starfsævi hans voru sett í brennidepil og markmiðið var að öðlast betri sýn á pað hvernig kennarinn starfar og hvers vegna. Ný hugtök voru próuð um pessa gildishlöđnu, persónulegu pekkingu kennarans, svo sem cognitions, beliefs, personal practical knowledge og subjective theories. Á íslensku hefur almennt verið notað heitið starfskenning 
um hugsun kennara um starf sitt. Starfskenning er persónubundin kenning sem byggist á siðferđilegum gildum auk pess sem hún hefur vitsmunalega og tilfinningalega vídd (Hafdís Ingvarsdóttir, 2014). Starfskenning virđist oft vera nátengd faglegri sjálfsmynd (e. professional identity) sem telja má kjarna kennarastarfsins (Hildur Hauksdóttir, María Steingrímsdóttir og Birna María B. Sveinbjörnsdóttir, 2018). Starfskenningin próast oftast íljósi reynslunnar, ekki síst ef kennarar ígrunda kennslu sína.

Einnig komu fram hugmyndir um að mikilvægt væri að fá fram lífssögu kennarans til að skilja betur starf hans, samanber spurningar Shulmans hér að framan um pað hvað skipti kennarann máli (Goodson, 1992b). Pessi áhugi á ađ rannsaka lífssögu kennarans endurspeglađi róttæk umskipti í skilningi okkar á kennslu og kennarastarfinu (Connelly, Clandinin og He, 1997). Nú purfti að líta svo á að kennsla væri samofin lífshlaupi kennarans og mikilvægi kennarastarfsins ætti að skođa og skilja í ljósi gilda fagmannsins. Kennarinn purfti sjálfur ađ fá rödd og segja frá eigin hugmyndum og gildum. Hvort tveggja mætti nálgast í samfelldri frásögn af persónulegri og samfélagslegri reynslu kennarans. Langtímamarkmið slíkra rannsókna er að bæta kennslu með pví að öđlast betri skilning á pví hvernig kennarar starfa og hvers vegna. pessi nálgun kallar, eins og áđur er getið, á pekkingarfræđilega endurskilgreiningu á pví hvernig rannsaka megi kennarastarfið.

\section{LEIĐIR AĐ HUGMYNDUM KENNARANS}

Pað sem einkum einkennir pær aðferđir sem hér verður fjallað um er að kennarinn sjálfur stýrir umræðuefninu svo að hugmyndir kennarans komi fram með sem minnstri íhlutun rannsakanda. Í hefðbundnum eigindlegum viðtölum er yfirleitt spurningarammi sem rannsakandi semur og síđan fylgir hann spurningunni eftir (e. probing) til að komast nær pví sem hann fýsir að vita. Hlutverk rannsakanda í gagnasöfnun samkvæmt peirri aðferð sem hér er lýst felst einungis í að velja leiðina en gefa síðan viðmælanda orðið. Í pessum rannsóknum er gefin umgjörð en ekki spurningalisti eđa spurningarammi sem hefur verið saminn fyrir fram.

Ekki er verið að leita eftir pví sem rannsakanda langar fyrir fram að vita heldur er markmiðið аð heyra hvað kennaranum sjálfum liggur á hjarta og hvað honum finnst mikilvægast að komi fram. pað sem einkennir slíkar aðferđir er að oftast er stuðst við munnlega frásögn pótt stundum geti pađ verið skrifleg frásögn ef kennarinn sjálfur kýs svo. Rannsakandi semur í framhaldinu drög að sögu sem kennarinn og rannsakandinn ræða svo saman um og loks verður hin endanlega saga til.

Hér eru dæmi um aðferðir sem reynst hafa vel og verið vænlegar til að átta sig á og skilja hugsun kennara:

- Frásagnir/lífssögur (e. narratives/life histories).

- Lífsfljót (e. rivers of life/career rivers).

- Sjálfskissur (e. self-characterisation sketches).

- Hugtakakort (e. concept maps).

- Rýnt í óvænt atvik (e. critical incident exploration).

- Greining á atvikum sem sköpuđu nýjan skilning (e. illuminative incident analysis).

- Rýnt í hluti og myndir.

(Byggt á Pope og Denicolo, 2001) 
Listinn gæti verið lengri og í rauninni er pað bara hugmyndaflugið sem takmarkar leiðirnar til ađ nálgast hugsun og hugmyndir kennara um starf sitt með lágmarks íhutun rannsakanda. Rýmisins vegna verður ekki hægt að fjalla um allar pessar aðferđir, uppruna peirra og próun, en hér er brugđið á pað ráð að taka dæmi af rannsókn sem höfundur gerđi á starfskenningum framhaldsskólakennara par sem stuðst var við fjórar ađferđir, pað er vettvangsathugun, lífsfljót, lífssögu og sjálfskissu. Vettvangsathugun parf ekki endilega að vera hluti lífssögurannsókna en er pađ oft.

Vettvangsathugun felur í sér, eins og orđið bendir til, að rannsakandi heimsækir pátttakanda og dvelur međ honum um tíma á vettvangi hans til að fá sem gleggsta mynd af umhverfi hans og skynja betur hinn mannlega pátt (e. naturalistic observation) (Adler og Adler, 1998). Í kennararannsóknum situr rannsakandi í kennslustundum og fylgist međ kennaranum í starfi. Ekki er ákveđið fyrir fram hversu oft eđa lengi dvalið er á vettvangi heldur er miðað við að pegar mettun (e. saturation) er nád, pað er ekkert nýtt kemur lengur fram, ljúki vettvangsheimsóknum.

Hér á eftir er rakið dæmi af rannsókn í samstarfi við einn kennara og henni fylgt eftir til að lesandi geti betur glöggvađ sig á ađferđunum og hvernig pær virka í reynd. Fyrst verđur pó fjallađ almennt um rannsóknarađferđirnar lífssögu, lífsfljót og sjálfskissu.

\section{Lífssagan}

Lífssagan er ein leiđin í pessari nálgun til ađ öđlast betri skilning á hugsun og starfi kennarans. Með pví að nota lífssögu er hægt að flétta saman líf og starf kennarans. Lífssaga sem rannsóknarađferđá rætur sínar í mannfræđi- og félagsfræđilegum rannsóknum sem stundađar voru á öđrum og priðja áratug síđustu aldar við Háskólann í Chicago. Lögð var áhersla á ađ skođa reynslu fólks í félagslegu og samskiptalegu samhengi (Denzin, 1999; Hafdís Ingvarsdóttir, 2013). Lífssaga sem fræđilegt hugtak getur verið flókin og getur öðlast margskonar merkingu, allt eftir pví hver túlkandinn er og frá hvađa sjónarhorni hann horfir (Tierney, 2000). Lífssagan er valdeflandi, viðmælandinn fær rödd með pví að segja sögu sína og vald til að skilgreina eigið líf (West, Alheit, Anderson og Merrill, 2007). Hún á pví einkar vel við pegar á að láta hugmyndir og skođanir kennarans heyrast.

Rannsakandi sem beitir lífssögulegri nálgun vill setja sig inn í og skilja lífssýn, gildi, viðhorf og tilfinningar einstaklinga og félagslegt umhverfi peirra en um leið efla pann sem segir sögu sína. Lífssagan getur hjálpađ til við ađ rjúfa einangrun sögumanns (West o.fl., 2007). Til marks um pað langar mig að vitna í kennara sem ég hafði setið hjá í kennslustundum og í framhaldi af pví áttum við góđa samverustund par sem hann rakti lífssögu sína sem varpađi ljósi á pađ hvernig hann kenndi og hvers vegna. Pegar við skildum sagđi hann:

pú veist ekki hvað petta samtal okkar hefur verið mér mikils virđi. Ég er búinn að kenna i 18 ár og á öllum peim tíma hefur enginn komiđ inn til mín og enginn verið tilbúinn að hlusta á mig tala um kennsluna mína.

Hér höfum við lítið dæmi um pað hvernig lífssagan getur valdeflt kennarann og rofið einangrun hans. 
Goodson (1981) heldur pví fram að mesti styrkur lífssögunnar sé ađ í henni megi komast að innsta kjarna hugsunar einstaklingsins og gefa honum færi á að tala á eigin forsendum. Síđan Goodson setti fram hugmyndir sínar á níunda áratugnum hefur lífssagan haldið áfram að próast. Dwyer, Davis og Emerald (2017) hafa nýlega gefið út bók um narratífar rannsóknir, Narrative Research in Practice: Stories from the Field, sem gefa gott yfirlit yfir helstu ađferđir innan lífssögurannsókna eins og pær hafa próast til dagsins í dag.

Með pví að fá kennara til ađ rekja lífssögu sína getur rannsakandinn öđlast skilning á pví hvers vegna peir kusu að verđa kennarar og hvernig kennarar peir urðu. Hver er sýn peirra á nemendur og hvernig haga peir starfinu í kennslustofunni og hvers vegna? Ekki síst er talið að lífssagan hjálpi kennurunum sjálfum að skilja betur og skilgreina hvað felst í eigin fagmennsku. Rannsakandinn og kennarinn vinna saman að pví að skapa samhengi úr sögunni með samtölum. Rannsakandinn skrifar pá drög sem hann ber undir kennarann sem getur pá gert athugasemdir og bætt við eða fellt niður orð eða setningar. Loks skrifar rannsakandinn hina endanlegu sögu.

Til skýringar kemur hér brot úr lífssögu annars kennara. Í pessu dæmi var kennarinn bara beđinn ađ rekja lífssögu sína og einu fyrirmælin voru pau ađ greina frá leið sinni ađ kennarastarfinu og rekja ferilinn. Misjafnt er hvar kennarinn vill byrja eđa telur ástæðu til að byrja en pessi kennari kaus að byrja pegar hann hóf skólagöngu. pegar hér er komið frásögninni er kennarinn að útskýra af hverju hann tók svona miklu ástfóstri við frönsku, sem leiddi svo síđar til pess að hann varð frönskukennari. En einnig kemur fram í pessari stuttu tilvitnun hvernig hans fyrsti frönskukennari hafđi áhrif á framkomu hans sjálfs sem kennara síđar meir.

Brot úr lífssögu:

Við vorum mjög langt á eftir, við sem höfđum verið í sveitaskólanum. Og pá var franska pað fyrsta sem ég byrja að læra alveg óháđ öllu öđru. Parna [í framhaldskólanum] var ég ađ byrja með alveg hreint borð. pau kunnu ekkert meira en ég í frönsku, hinir krakkarnir. Pannig að ég purfti ekkert að vera með minnimáttarkennd yfir pví að hafa ekki fengið sama grunn og hinir. pá leið mér miklu betur, pá purfti enginn að vita neitt. Svo franskan varð strax svona metnađarmál og ég fékk kennara sem ég kunni ágætlega viđ og var duglegur að hrósa mér. pá áttađi ég mig á pví að pađ er nú alveg skelfilegt hvað kennararnir geta skipt miklu máli, alveg skelfilegt.

Pessi lífsreynsla mótađi hugmyndir kennarans um kennarastarfið og pegar hann sjálfur fór að kenna var honum pessi reynsla ofarlega í huga.

Rétt er ađ benda á ađ lífssaga er ekki bara persónuleg endursögn á lífi fólks, eins og ævisagan. Lífssaga dregur fram ákveđna pætti og varpar á pá skarpara ljósi (Goodson, 1992b; Measor og Sikes, 1992), auk pess sem hún dregur fram persónubundna túlkun á atburðum í lífi einstaklings (Diamond, 1991). 


\section{Lífsfljótið}

Líkja má lífssögunni við fljót par sem hver bugđa markar atburð sem orđið hefur til pess að breyta framrás fljótsins (Pope og Denicolo, 1993, 2001). Pessar bugđur tákna afgerandi atvik sem valda straumhvörfum í lífi einstaklings (Kelchtermans, 1993). Ferlið hefst á pví að kennarinn er beđinn að rifja upp líf sitt og draga upp mynd af pví eins og bugđóttu fljóti. Hver bugđa táknar liđin atvik, atburđi, lífsreynslu sem hefur haft afgerandi áhrif á líf hans og leitt hann pangađ sem hann er nú (Pope og Denicolo, 2001). Mikilvægt er að gefa viðkomandi tíma til að draga fljótið upp og gera pað helst í einrúmi. Hafa ber í huga að pessi tækni getur gengið nærri pátttakendum. Dví er mikilvægt að rannsakandi byrji á að gera petta sjálfur til að skilja hvað hann er að leggja á viðmælandann.

pađ sem vinnst við pessa leið er međal annars ađ hún hjálpar kennaranum ađ ígrunda með markvissum hætti. Viđtalið er síđan byggt á lífsfljótinu. Augljós kostur pess er að kennarinn sjálfur stýrir viðtalinu, lífsfljótið stýrir pví um hvað er rætt. Í viðtalinu, pegar pessi atvik í lífsfljótinu eru rædd, gefur hann skýringu á pví hvers vegna pessi atvik eđa atburđir eru honum minnisstæđir og hvađa áhrif peir höfđu á líf hans. Hlutverkin snúast pannig við frá hefðbundnum viðtalsrannsóknum. Viðmælandinn (kennarinn) er sérfræðingurinn sem er að segja söguna eins og hann kýs að segja hana. Sögumaður er höfundur handrits, leikari og leikstjóri en rannsakandi er í hlutverki hins áhugasama áhorfanda, túlkanda sögunnar. Rannsakandi greinir síđan fljótið til að finna pemu og óvænt atvik. pemun úr lífsfljótinu mynda pannig leiđarstef í framsetningu á sögunni (Hafdís Ingvarsdóttir, 2013).

Hér er dæmi um lífsfljót kvenkennara, Maríu (nafn sem hún valdi sjálf), en hún hefur kennt í rúmlega 30 ár og nálgast nú starfslok:

- Skólaleikur.

- Stúlka í karlaveröld.

- Ókunnar slóđir.

- Grýtt byrjun.

- Móđir.

- Fullorđinsfræđsla.

- Framhaldsskólakennarinn.

- Að læra meira og meira.

- Með fagmennskuna í fyrirrúmi.

Upp úr bugðunum komu ofangreind pemu sem samtalið byggđist síđan á. Rannsakandi setur saman drög að sögu upp úr samtalinu, sem kennarinn fer yfir og gerir athugsemdir við ef honum pykir eitthvað ofsagt eða vansagt. Frumsagan (e. interim story) er byggð utan um pemun. María hefur farið vandlega yfir frumsöguna og hugsanlega breytt einhverju pví nýr skilningur og ný saga getur skapast við að lesa frumsöguna. Lokasagan er framlag peirra beggja, kennarans og rannsakandans. Vert er einnig að minna á að rannsakandi er óhjákvæmilega hluti af rannsókninni, en til að áhrifa hans gæti sem minnst parf hann að líta í eigin barm og gera sér sem best grein fyrir eigin afstöđu og skođunum. pungamiðja rannsóknarferlisins er nánd, trúverđugleiki og fölskvaleysi í samskiptum sögumanns og rannsakanda. Eđli peirra samskipta skiptir sköpum um gæđi rannsóknarinnar og pekkingarsköpunina (Knowles, 20017). Frásögn kennarans má aldrei litast af pví 
sem rannsakanda er umhugađ um ađ sé sagt. Rannsakandinn parf ađ byrja á ađ segja sér sína sögu pví pá getur hann betur skilið hvað hann er að fara fram á og er frekar á varðbergi gagnvart eigin viðhorfum við túlkun sögunnar. Petta gildir í raun um allar leiđir innan pessarar rannsóknarhefđar.

\section{Sjálfskissur}

Sjálfskissur eiga rót sína ađ rekja til sálfræđingsins George Kelly (1955) sem notađi pær við klíníska međferđ skjólstæđinga sinna. Hann bađ pá að skrifa lýsingu á sjálfum sér eins og hliđhollur vinur sæi pá. Ég hef próađ pessa hugmynd og notað hana í vinnu međ kennurum. Ég hef beđið kennara að taka upp kennslustund að eigin vali og fjalla um kennarann sem peir sjá og horfa á upptökuna međ augum góđs samstarfsfélaga. Rétt er að taka fram að kennurum finnst petta erfitt, enda yfirleitt ekki pjálfađir í slíkri sjálfsskođun. í pessu tilviki, eins og gildir í öđrum peim ađferđum sem kynntar eru hér, er mikilvægt að rannsakandinn byrji á sjálfum sér, til dæmis með pví að taka upp kennslustund og reyna að skođa upptökuna með augum félaga.

Einnig má nota sjálfskissur við starfspróun kennara sem geta pá gert pær með nokkurra mánađa (jafnvel ára) millibili og skođađ hvort og hvernig peir hafa vaxið í starfi. Höfundur vill nefna að hún hefur notað sjálfskissur sem lokaverkefni í námi verđandi kennara. Markmiđið hefur verið að pjálfa pá í ađferð sem getur nýst peim í áframhaldandi starfspróun.

Hér fylgir dæmi um sjálfskissu frá kennara (dálítið stytt rýmisins vegna):

- Pað mikilvægasta sem mér fannst koma fram er að pessari konu finnst gaman að kenna og líđur vel međ nemendum sínum. Auðvitað er pað pess vegna sem hún er kennari. Mér fannst ég sjá yfirvegađan kennara sem nýtur pess að kenna.

- Hún virkjar nemendur, reynir að tengja námsefnið við reynsluheim peirra. Hún útskýrir tilgang verkefnanna.

- Hún gerir eitthvađ úr purri æfingu í bókinni, ef hægt er - fer ekki bara yfir.

- Hún pekkir tilgang æfingarinnar, til dæmis endurtekur orð sem parf að læra til að stađfesta merkingu. Parna stoppađi ég og fór að hugsa um hvort hún endurtæki of mikið eða færi of hægt yfir.

- Hún brosir mikið.

- Hún skapar eftirvæntingu.

- Hún gefur nemendum reglulega tækifæri til að spyrja spurninga.

- Hún er jákvæð.

- Hún reynir ad láta nemendum líđa vel.

- Hún fær nemendur til að hugsa og finna orð eđa tengd orđ til að tjá sig í stađinn fyrir að hún gefi svör.

- Hún tekur vel í alls konar svör og vinnur með pau.

- Hún heldur athygli nemenda ágætlega.

- Hún er vingjarnleg við nemendur.

- Hún er meðvituð um að tala ekki niður til nemenda.

- Hún endar tímann vel.

- Hún hefur fulla stjórn á bekknum. 
Kennarinn tekur að lokum fram að petta hafi verið mjög hefðbundinn tími, en sjálfskissan byggist á upplifun kennarans á einni kennslustund.

Hér á eftir verður saga Inga rakin með peim aðferðum sem hér hafa verið kynntar. Hver kennslustund stóð í eina klukkustund og par sem sögumaður kennir mörgum og fjölbreyttum hópum lagđi rannsakandi áherslu á að fá að vera viðstödd kennslu í mismunandi hópum.

Áđur en lengra er haldið er rétt að leggja áherslu á hina siðferđilegu hlið á pessari rannsóknarhefð. Rannsakandi er hreinlega að biđja um að fá að ganga inn í líf sögumanns, fá hann til að horfast í augu við eigin lífssögu og deila henni með öđrum. Að skapa traust á milli ađila er pví alltumlykjandi í pessum samskiptum. Mikilvægt er að hafa í huga nú sem oftar að ađgát skal höfð í nærveru sálar.

Við ritun pessarar greinar hefur ýtrustu varkárni verið gætt til að halda nafnleynd eins og heitið var. Nöfn pátttakenda svo og stofnana og deilda eru gervinöfn. Eins og sjá má hér að framan gera pessar aðferđir miklar siðferðilegar kröfur til rannsakanda; næmi og varfærni gegna lykilhlutverki. pað er mikilvægt að árétta að hafa verður í huga á öllum stigum ferlisins að sagan er eign sögumanns og hann parf að sampykkja skrifin og heimila birtingu (Hafdís Ingvarsdóttir, 2013).

\section{INGI}

Ég byrja á að sitja í kennslustundum hjá Inga og bið um að fá að fylgjast með honum kenna mismunandi hópum. Að loknu hverju áhorfi á ég við hann stutt samtal par sem ég bið hann að skýra nokkur atriđi ef pörf pykir. Í framhaldi af pessu er Ingi beđinn að draga upp lífsfljót sitt sem síđan er pemagreint og Inga er svo gefið orðið til að ræða og dýpka bađ sem fram kemur í lífsfljótinu. Hann rekur lífssögu sína, byggđa á lífsfljótinu, og endar svo á að skrifa sjálfskissu. Hans skissa er reyndar óvenju stutt, en honum fannst petta fremur erfitt og pá er mikilvægt að rannsakandi skynji pað og prýsti ekki á að kennari geri eitthvað sem hann er ófús til, svo sem að skrifa lengri skissu. Lengri og dæmigerðari skissa var sýnd hér að framan.

\section{Kennarinn Ingi}

Ingi varð kennari fyrir hreina tilviljun. Hann er međ meistarapróf í ensku og diplómanám til kennsluréttinda. Ingi hefur pegar hér er komið sögu kennt i 16 ár. Hann kennir í nokkuð stórum skóla sem býđur upp á bæđi verklegt og bóklegt nám. Par hefur líka tíđkast að bjóđa upp á síđdegis- eđa kvöldnám fyrir eldri nemendur og kennir Ingi einnig par.

Fyrsta heimsókn mín er á dimmum og votum febrúarmorgni. Skólabyggingin er stór, margir gangar og ekki auđvelt að rata. Ég finn leið upp á efri hæđina eins og Ingi var búinn að leiðbeina mér. Pegar ég birtist í dyragættinni á vinnuađstöđunni hans stendur hann upp og býđur mig velkomna á sinn elskulega og prúđa máta og við göngum til kennslustofunnar. 


\section{Svipmyndir úr skólastofunni}

prátt fyrir að klukkan sé orđin átta eru bara sex nemendur mættir og peir sitja dreifđir um skólastofuna. Ingi heilsar peim á ensku og býđur góđan dag. Hann skilur dyrnar eftir opnar og smám saman tínast fleiri nemendur inn. Hann heilsar öllum með bví að ávarpa pá: „Good morning, good to see you.“ Og pegar sá allra síđasti kemur segir hann: „We are pleased to see you, Dóra, although you are late." í kennslustofunni ríkir friđsælt og afslappað andrúmsloft og pað einkennir allar kennslustundirnar sem ég sit. Ingi talar lágri röddu og nær einvörðungu á ensku. Hann byrjar ævinlega tímana á að skrifa á töfluna hver viðfangsefni dagsins eru og merkir síđan við jafnóđum pegar peim pætti er lokið. Pennan morgun skrifar Ingi á töfluna:

- Homework.

- Page 12, 13, 15 [exercises].

- Listening comprehension.

- Conversation "Why English".

- "Waiting for the police" [an article].

Pótt Ingi byrji tímana oftast á pennan hátt virđist hann laga kennsluna ađ hverjum hópi fyrir sig. Stöku sinnum byrjar hann á að gefa nemendum verkefni til að leysa á međan hann gengur um og ræđir hljóđlega við hvern nemanda um hvernig gangi. Heyri ađ hann segir við piltinn sem situr næst mér: „How are you doing, sir? Have you caught up with us yet?"

Ingi spyr nemendur einslega hvort pađ séu einhver vandamál og lítur stuttlega yfir heimavinnuna. Í sumum tímum heilsar hann bara hópnum, segir nokkur hvetjandi orđ og byrjar síđan á fyrsta verkefninu á listanum. Hann nýtir hvert tækifæri pegar nemendur eru að vinna til að nálgast pá einslega. [Hann útskýrir seinna aðspurđur fyrir mér: „Peir segja pér ekki frá vandamálum sínum fyrir framan allan bekkinn."] Hann leggur gjarnan höndina á öxl nemandans međan hann er að tala við hann. Pað heyrast setningar eins og: „You are on your way, sir" eða „this is fine“. Hann segir við einn nemandann, sem virðist hafa dregist aftur úr og sýnist vondaufur: „By all means, stay tuned, you will catch up with us.“

pótt Ingi hækki aldrei röddina er hann mjög ákveđinn. Pessi ákveđni er mest áberandi pegar hann er að kenna hópi nemenda sem hafa fallið í ensku á grunnskólaprófi. Petta var líka eini hópurinn sem hann talađi íslensku við að einhverju ráđi: „Sum ykkar mættu ekki í gær. Hvers vegna var pađ?“ Petta er fámennur hópur og hann biđur hvern nemanda um skýringu. Hann heldur síđan áfram á íslensku og segir peim sögu af stúlku sem var í pessum hópi í fyrra en er nú komin í almennan hóp og gengur vel og hann segir hvernig henni tókst petta: „Svo, að mæta vel og vinna samviskusamlega er lykillinn. Mig langar að ykkur gangi vel og ég veit að ykkur langar sjálf að standa ykkur."

Hann pekkir alla međ nafni og jafnvel bakgrunn peirra, en pó voru ađeins liđnar prjár vikur af önninni, og hann kennir átta hópum, en sumir eru reyndar mjög fámennir. [Pegar ég spyr seinna af hverju hann hafi ekki gert athugasemdir við pilt sem var bókarlaus segir hann: „Hann hefur ekki efni á að kaupa bækur hann á enga að.“] Hann virđist einbeita sér að pví að leggja rækt við hvern einstakan nemanda, næstum eins og nemandinn sé viðkvæm planta. 
Ingi notar kennslubækur í nær öllum áföngum en hann dreifir líka ljósritum, til dæmis úr Time eđa öđrum tímaritum, eftir pví hversu langt nemendur eru komnir. Eitt sinn tók ég eftir að hann dreifđi tvenns konar greinum. [Hann útskýrđi pá fyrir mér að hann reyndi að koma til móts við pað að nemendur hefðu ekki endilega sömu áhugamálin.] Hann stendur ekki mikið uppi við töflu nema pegar hann er að fara yfir málfræđi- eða hlustunaræfingar. pá gætir hann pess að láta nemendur alltaf koma međ svörin og spyr hversu oft peir vilji heyra textann í hlustunaræfingunum. Mestur tími fer í alls konar para- eđa hópavinnu. pað er greinilegt að Ingi nýtur kennarastarfsins og pað var erfitt að skilja hvernig hann fór að pví að vera alltaf áhugasamur og hvetjandi, ekki síst pegar hann kenndi svo mörgum og ólíkum hópum.

Ég sat í tímum klukkan átta á morgnana og átta á kvöldin. Hann var alltaf sá sami, mjög kurteis, hækkaði röddina nær aldrei, sýndi nemendum mikla virðingu og sú virđing virtist gagnkvæm. Andrúmsloftið var hlýtt og pað var oft slegið á létta strengi. Nemendum virtist líka vel pegar hann kallađi pá sir eđa madam eđa gentlemen sem hann gerđi jafnan: „Gentlemen, you two will work together." Hann kenndi afar ólíkum hópum, allt frá nemendum sem ekki höfðu náð grunnskólaprófi til nemenda sem voru komnir í efstu áfanga, og kom fram af sömu virðingu og kurteisi við alla hópa.

pegar vettvangsheimsóknum er lokið setjumst við Ingi niður og ég bið um skýringar á ýmsu sem ég varđ vör við, samanber nokkrar athugasemdir í hornklofum hér að framan.

\section{Kennari í mótun}

Eftir að hafa horft á pessa tíma með Inga vaknar spurningin: Hvað mótar slíkan kennara? Hvernig varð hann pessi kennari? Til að öđlast betri skilning á pví fáum við Inga til að rekja lífssögu sína. Við byrjum á að biðja hann ađ teikna upp lífsfljót sitt (sjá umfjöllun hér að framan). Að pví loknu pemagreinir rannsakandi (ég) lífsfljótið:

\section{Lífsfljót Inga}

Hér eru pemun sem komu fram pegar Ingi dró upp lífsfljót sitt:

- Tilviljun.

- Reynsluár.

- Íl leit ađ faglegri sjálfsmynd.

- Fagmađur að störfum.

- Nýjar áskoranir.

- Kennari fyrst og fremst.

pessi pemu leggja grunninn ađ frásögn hans. 


\section{LÍFSSAGA INGA}

Hér fer á eftir lífssaga Inga, sem hann rekur með hliđsjón af pemunum sem upp komu pegar hann dró upp lífsfljót sitt.

\section{Tilviljun}

Pað voru einkum tvö atvik í lífi mínu sem gerđu að ég varð kennari. Ég valdi að fara í viðskiptafræđi í háskólanum. pađ reyndist mistök pví viðskiptafræđin átti alls ekki við mig, og pađ var hrein tilviljun ađ ég lenti í kennslu. Ég fylgdi bara félögunum úr menntaskóla en strax á fyrstu vikunum áttađi ég mig á ađ viðskiptafræđi höfđađi ekki til mín. Ég hætti pví strax eftir nokkrar vikur. Pađ sem eftir lifđi vetrar vann ég verkamannastörf en undir vorið var ég beđinn ađ hjálpa nokkrum grunnskólanemum með stærđfræđi fyrir samræmdu prófin. Mér fannst petta mjög skemmtilegt og fann að petta átti vel við mig svo pađ má segja ađ hrein tilviljun hafi ráđið lífsstarfi mínu.

Ég fór pá aftur í háskóla og innritađist í ensku og sögu pví petta voru eftirlætisgreinar mínar í menntaskóla. Ég fór í pessar greinar gagngert til ađ verđa kennari. Ég hóf síđan kennslu við grunnskóla og kenndi á unglingastiginu. Petta var mjög erfitt í byrjun. Ég var ungur og reynslulaus. Ég minnist pess ađ ég reyndi snemma að koma mér upp góđu skipulagi og vera ákveđinn til ađ geta haldið uppi góđum aga. Og pegar ég lít til baka sé ég að innihaldið eđa námsefnið virđist ekki hafa verið aðalatriðið. pess í stað var pað pessi rammi sem var svo mikilvægur og gerði mér lífið léttara. Einnig gerđi pað samskipti mín við nemendur auðveldari ađ ég fór fljótlega að starfa í félagslífinu. Pað var mjög gefandi. Í pví hlutverki kynntist ég nemendum frá annarri hliđ, sem var mjög hjálplegt og gaf mér betri innsýn inn í heim unglinganna. Parna var ég meira sem eldri félagi pótt ég væri auðvitađ ekki jafningi peirra. Mér féll kennslan svo vel að ég ákvað að fara í meistaranám í ensku. Mér fannst námið hrista upp í mér, vera bæđi örvandi og uppbyggilegt. Eftir nokkurra ára kennslu flutti ég til útlanda ásamt eiginkonu minni sem fór í nám.

\section{Reynsluár}

Ég fékk enga vinnu erlendis og var atvinnulaus í 18 mánuđi pangað til ég fékk starf sem aðstođarkennari. Mér var ætlað að aðstođa nemendur sem voru verst staddir en starfsfólkið var ekki mjög faglegt að mínu mati. Ég vann í pví sem peir kölluđu „The Clinic“ og pað var sérúrræđi fyrir pá sem áttu í ýmsum erfiðleikum. Ég minnist barns sem hafđi lent í alvarlegum sifjaspellum og sum börnin voru sködduð fyrir lífstíð. Held að mér hafi fundist ég vera að leggja eitthvað af mörkum parna. Á pessum árum vann ég ýmis önnur störf en pað voru allt störf með ungu fólki sem átti við vandamál að stríða.

Almennt fannst mér starfsfólkið ekki vera starfi sínu vaxið, ekki nógu faglegt. Kennararnir voru helstu andstæđingar mínir pví ég vildi hafa aga. Fólk má ekki komast upp með að hegđa sér eftir eigin geđpótta. Tíminn parna var erfiður en dýrmætur. Eftir fimm ára dvöl erlendis sneri ég aftur heim og fór að kenna í stórum framhaldsskóla. Ég fann að ég var ekki sami kennarinn og áđur en ég fór utan. Ég var meira eins og hestur međ blöđkur fyrir augunum. Ég hafđi ekki sömu yfirsýn yfir starfið og fyrr. Pegar ég rifja petta upp sé ég að pað tók mig langan tíma að ná fyrri hæfni. 


\section{Í leit að faglegri sjálfsmynd}

Ég var að leita að nýrri sjálfsmynd sem framhaldsskólakennari og jafna mig á reynslunni erlendis. pađ tók sinn tíma. Skólinn var stór og flókinn og skiptist í margar ólíkar deildir. pað sýndi sig svo að ekki var næg enskukennsla og mér var boðið að uppfylla kennsluskylduna við Menntabraut (gervinafn) sem var fyrir ungmenni sem voru líkamlega fötluð eđa međ geđraskanir, en brautin var á pessum tíma rekin í samstarfi við framhaldsskólann.

Ég sá ekki eftir að hafa pegið petta starf. petta er mjög góð deild og vel hugsað um nemendurna. Pað var gott að vinna parna. Pað voru vikulegir starfsmannafundir og nemendum vel sinnt. Petta var krefjandi starf en mjög gefandi á marga vísu. Á vissan hátt var petta eins konar endurmenntun fyrir mig. Parna voru námsráđgjafar, starfsráđgjafar og sálfræđingur. Við unnum náið saman og við ræddum á hreinskiptinn hátt um vandamál hvers nemanda. Við unnum í teymum og unnum á opinskárri og vandađri hátt en tíđkast í almennum skólum. Hér fannst mér ég loksins vera međal fagfólks.

\section{Fagmaður að̃ störfum}

Í dag starfa ég í öđrum stórum framhaldsskóla og mér líđur vel í pessum skóla en ekki af pví að skólinn hafi gert neitt til pess að láta mér líđa vel. Mér finnst bara gaman að kenna. pað er ekkert leyndarmál að pessi stofnun hefur ekki komið sérlega vel fram við kennara sína. Sú framkoma hefur leitt til mikillar samstöđu međal kennara en pessi samvinna sem ég kynntist áđur er ekki hér. pađ er ólíkt að kenna í grunnskóla og framhaldsskóla pað eru ólíkar hefðir og venjur sem pú parft að aðlagast.

Mér fannst ég burfa að nálgast kennslu frá nýju sjónarhorni. Áđur fannst mér innihaldið ekki svo mikilvægt en pað hefur breyst. Innihaldið og hvernig efnið er sett fram skiptir öllu máli hér. pað skiptir enn meira máli á pessu stigi að efnið höfđi til nemenda. Pú parft stöđugt ađ hafa í huga ađ gera kennsluna fjölbreytta og áhugaverđa fyrir nemendur.

pað hefur tekið mig langan tíma að próa hugmyndir mínar um kennslu. Einkum pessa auknu meðvitund um mikilvægi pess að hafa kennsluna fjölbreytta. Nemendur hafa áhrif á mig og láta mig vita ef peim líkar ekki viđfangsefnið. Ég er líka óhræddur við að prófa eitthvað nýtt. Ja, ef ég á að vera alveg heiđarlegur pá fer pað svolítið eftir hópnum. pú finnur að sumir hópar eru, við skulum segja, meira tilbúnir að reyna eitthvað nýtt en ađrir. Mér finnst enn jafn mikilvægt að vera skipulagður og hafa góðan vinnuaga, gott andrúmsloft og innihald sem vekur áhuga. Petta parf allt ađ fara saman, eins og ég segi stundum við nemendur: Petta er pað sem skólinn, kennarinn og nemendur purfa að vinna að í sameiningu. Ef petta vinnur allt saman erum við búin að leggja grunn að góðu starfi.

Mér finnst óábyrgt ađ skipuleggja kennsluáætlunina í smáatriðum áđur en ég hitti nemendur mína. Svo bætast stundum nýir nemendur við svo ég parf að hafa dálítinn sveigjanleika. pað parf að laga kennsluáætlunina að pörfum nemendanna. Ég lærđi á Menntabrautinni par sem ég var áđur hversu mikilvægt er að hafa gott andrúmsloft og hvað pađ skiptir miklu máli ađ nálgast nemendur sem einstaklinga. pú getur bara ekki leyft pér ađ vera fjarlægur, pú parft að gefa af pér og í stað pess ađ hugsa: Pessi, hann mun aldrei geta neitt pessi auli, pá ættir pú í staðinn að hvetja hann. Pá færðu kannski svör eins og: „Ég er nefnilega lesblindur og mér finnst petta mjög erfitt.“ pađ er oftast eitthvað í pessa veru sem að baki liggur. 
Hugmyndir mínar um kennslu koma úr mörgum áttum og auđvitað fylgja mér draugar úr eigin skólagöngu, en ef ég rekst á eitthvað sem ég held að myndi henta vel í minni kennslu pá, já, ég fæ bara hugmyndir úr ýmsum áttum. Ég kenni ađallega á ensku og geri pađ meir og meir. Ég held að vera mín erlendis hafi haft áhrif á pađ. pegar mađur býr erlendis pá áttar pú pig á að pú notar tungumálið mest til að tala en ekki skrifa og pað gagnast pví nemendum best ađ enska sé töluð í kennslustofunni.

\title{
Nýjar áskoranir
}

Fyrir nokkrum árum var mér bođið að vera áfangastjóri fyrir öldungadeildina. Mér fannst pað vera áskorun að takast á við pað og hefði pá sagt að ég væri fyrst og fremst stjórnandi í eđli mínu og kennarinn kæmi númer tvö. Mér líkuđu stjórnunarstörfin vel en pegar ég rifja petta upp man ég að mér fundust pau vera farin að stela tíma frá kennslunni. Eftir sjö ár sem stjórnandi hætti ég pví ég áttađi mig loks á að ég er fyrst og fremst kennari svo að við síđustu bugđuna i lífsfljóti mínu stendur: „Áttađi mig á að ég er fyrst og fremst kennari með stóru K. par slær hjartað.“

\section{Sjálfskissan}

Ingi var síđan beđinn að skrifa sjálfskissu. Hann tók svolítið treglega í pađ, hélt að pað yrđi sér erfitt, en sendi mér svo skissuna nokkrum dögum seinna. Ingi kemur sér beint ađ efninu, en oft láta kennarar fylgja stuttan formála. Gefum Inga orđið:

\begin{abstract}
Kennarinn er hægur, rólegur og yfirvegađur og fátt virđist koma honum úr jafnvægi. pađ má sjá ađ hann kann vel viđ sig í starfi pví hann er yfirleitt léttur og virđist eiga létt međ samskipti við nemendur. Hann reynir ađ láta nemendum líđa vel. Hann er duglegur að virkja nemendur og útskýrir tilgang verkefnanna. Hann er alltaf vingjarnlegur og er meðvitaður um að tala ekki niður til nemenda. Hann heldur athygli nemenda ágætlega.

Hann hefur góđan aga í tímum og hefur greinilega mikla polinmæđi bví annars myndi hann ekki sækjast eftir að kenna hópum sem standa höllustum fæti. Í stað pess að einblína á kennslu í efri áföngum eins og margir kjósa kennir hann í mjög mörgum mismunandi hópum. Petta eru að sjálfsögðu međmæli með manninum. Eftir að hafa verið mest við stjórnun undanfarin ár er hann greinilega mjög sáttur við að hafa snúið aftur alfarið í kennslu.
\end{abstract}

\section{SAGAN Í SÖGUNNI}

Saga Inga sýnir okkur berlega hvernig hann hefur mótast sem kennari. Ljóst er að kennsla heillar hann frá fyrstu kynnum. Áhugi hans á nemendum vaknar snemma og tengsl við nemendur mynda kjarnann í starfskenningu hans. Pessi tengsl vill hann byggja upp með pví að skapa notalegt andrúmsloft par sem ríkir gagnkvæm virđing og traust. Hann lítur á pessi tengsl sem grundvöll pess ađ ná árangri í kennslunni. Hér endurspeglast grunngildi hans; virðing og umhyggja sem eru honum leiđarljós í starfi. Sigrún Ađalbjarnardóttir (2007) telur að virđing birtist međal annars í að veita nemendum athygli, hlusta á pađ sem peir hafa að segja og eitt einkenni umhyggju kennarans sé að hann sýni nemendum 
samlíđan og samúđ. Hvort tveggja gengur sem rauđur práđur í gegnum öll samskipti Inga við nemendur.

Í rannsóknum kemur víđa fram að fyrsta árið sé mörgum prautaár og ýmsir óvæntir erfiðleikar mæti nýjum kennurum, en peir erfiđleikar eru bæđi sameiginlegir og einstaklingsbundnir (Loughran, 1996). Ingi nefnir ekki neina slíka erfiðleika og virđist frá upphafi líđa vel í kennslu. Pað er athyglisvert að Ingi talar heldur ekki um samvinnu og áttar sig ekki á mikilvægi hennar fyrir starfspróun fyrr en hann fer að starfa á Menntabrautinni og virðist ekki hafa kynnst samvinnu að neinu marki fyrr en par. pað styður kenningar um eyjamennsku (e. balkanisation) (Hargreaves og Fullan, 2012) í íslenskum skólum. Íslenskar rannsóknir hafa bent til pess að kennarar, einkum framhaldsskólakennarar, starfi oft í einangrun á eins konar afmörkuđum fageyjum (Hafdís Ingvarsdóttir, 2018; Hildur Hauksdóttir o.fl. 2018).

Reynsla Inga af pví að vinna erlendis með börnum og unglingum sem áttu við ýmsan félagslegan og tilfinningalegan vanda ađ etja hefur augljóslega haft áhrif á starfskenningu hans en ekki síđur vinna hans međ nemendum á Menntabraut. Við pessa reynslu mótast sú sannfæring hans að til að ná árangri purfi ađ ná til hvers og eins nemanda, láta nemandann finna að kennaranum sé ekki sama og að hann vilji veg nemandans sem mestan.

Eftir að hafa starfað í mörg ár erlendis finnst Inga erfitt að fóta sig og ná áttum í kennslunni heima. Pegar hann fer svo að starfa við Menntabrautina finnur hann aftur kennarann í sér, pað er, sína faglegu sjálfsmynd, enda segir hann að starfið par hafi verið nokkurs konar endurmenntun. Á Menntabrautinni hefur greinilega myndast pverfaglegt lærdómssamfélag, en Lave og Wenger (1991) halda pví fram að mannshugurinn proskist fyrst og fremst í félagslegum samböndum. Petta félagslega samband starfsmanna á Menntabrautinni átti eftir ađ hafa veruleg áhrif á starfskenningu Inga eins og hún birtist síđar í starfi hans og gera hann mun međvitađri um hana.

Athyglisverđ próun verđur á viðhorfum Inga til viðfangsefnanna og áherslu á pau á ferlinum. Í upphafi kennslunnar, pegar hann kenndi við grunnskóla, var hann augljóslega mjög upptekinn af umgjörðinni, skipulaginu og aganum. Hvort tveggja eru algeng viðbrögð nýliða í kennslu. Nýliđinn virđist ekki hafa bolmagn til að huga að öllum páttum starfsins í einu (Fantilli og McDougall, 2009) og í byrjun finnst honum jákvæður agi og festa vera undirstađa árangurs í starfi. Worthy (2005) bendir á pađ ađ nýir kennarar purfi frá fyrsta degi að taka að sér skyldur og ábyrgð reynds kennara, par á međal bæđi kennsluna og ađ stýra heilum bekkjum. Leið Inga til ađ ná tökum á bekkjarstjórnun er ađ skapa skýran ramma og festu. Sama gildir í störfum hans erlendis, par sem hann starfađi með börnum sem höfðu orðið utanveltu í kerfinu. Hann taldi að pau pyrftu aga og festu og lenti pá oft í andstöđu við samstarfsfólk sitt sem hafđi aðrar hugmyndir.

Inntakið, námsefnið, er honum síđur hugleikið í upphafi starfsins. Sú hugsun breytist með auknum starfsproska. Hann hefur bætt við sig meistaranámi í kennslugreininni og við pað myndar hann hugsanlega sterkari tengsl við fagið, og hann segir: „Námið var bæði uppörvandi og uppbyggilegt." Í rannsóknum með fagkennurum hafa komið fram kenningar um að með frekara námi eflist fræđileg tengsl við greinina. Pekkingin er páttur í persónulegri reynslu og er bæði fræðilegs og tilfinningalegs eðlis (Pope og Denicolo, 2001).

pegar hér er komið sögu er Ingi líka farinn að kenna sérgrein sína við framhaldsskóla par sem faggreinin gegnir enn stærra hlutverki en á öđrum skólastigum. Hann hefur fyrir 
löngu fundið kennslustíl sem samræmist starfskenningu hans og hefur próað og náð valdi yfir skipulaginu. Hann getur pví einbeitt sér betur að greininni og framsetningu hennar. Starfskenning hans hefur próast, víkkað og dýpkað. Hún nær nú, auk rammans, til nemenda sem einstaklinga, til námsefnis og hann er sér međvitađur um pörfina á fjölbreytni í framsetningu.

Mikilvægur liđur í starfspróun kennara er ađ peir séu sér međvitađir um eigin starfskenningu, og pað virđist Ingi vera. Að próa eigið starf er námsferli og í pví felst að endurskođa parf eigin starfskenningu áđur en einhver breyting getur orđið á sjálfri kennslunni (Pope og Denicolo, 2001). Til að svo megi verđa purfa kennarar að skilja hvernig starfskenning peirra hefur mótast og hvað hefur haft áhrif á próun hennar (Hafdís Ingvarsdóttir, 2014). Með pví að rekja lífssögu sína verđur Inga endanlega ljóst hvađa gildi eru hans leiðarljós, hvar styrkur hans liggur og hvar hjarta hans slær, eins og glögglega kemur fram í sjálfskissu hans. Samkvæmt dæminu af Inga eru bað ekki endilega kennsluaðferðirnar sem skera úr um gæđi og árangur kennslunnar heldur virðast umhyggja og samskiptin við nemendur gera gæfumuninn.

\section{LOKAORĐ}

Í pessari grein hefur verið lýst fjórum ađferđum við að lađa fram hugsun og hugmyndir kennara um starf sitt. Sögu Inga er ætlað að sýna hvernig pessar tegundir aðferða leiða petta fram og hvernig framkoma hans í kennslustofunni endurspeglar hugmyndir hans og viðhorf. pað er von höfundar að pessi grein megi vekja áhuga ungra rannsakenda á að stunda rannsóknir í pessa veru. Pær gefa ómetanlega innsýn og skilning á starfinu og geta um leið eflt faglegan styrk kennarans. Pótt hér sé kennarinn og kennarastarfið í brennidepli geta pessar rannsóknarađferđir nýst við ađ varpa ljósi á hugmyndir ýmissa annarra starfsstétta og stuðla um leið að frekari vexti fólks í starfi. Höfundur greinarinnar vill að lokum færa Inga einlægar pakkir fyrir að deila sögu sinni og leggja pannig lóð á vogarskálarnar við að efla skilning okkar á kennarastarfinu og próun pess.

\section{HEIMILDIR}

Adler, P. A. og Adler, P. (1998). Observational techniques. Í N. K. Denzin og Y. S. Lincoln (ritstjórar), Collecting and interpreting qualitative materials (bls. 79-109). Thousand Oaks: SAGE.

Calderhead, J. (1987). Teaching as a professional thinking activity. Í J. Calderhead (ritstjóri), Exploring teachers' thinking (bls. 1-19). London: Cassell.

Clark, C. M. og Peterson, P. L. (1986). Teachers' thought processes. Í M. C. Wittrock (ritstjóri), Handbook of research on teaching (3. útgáfa, bls. 255-296). London: Macmillan.

Connelly, F. M., Clandinin, D. J. og He, M. F. (1997). Teachers' personal practical knowledge on the professional knowledge landscape. Teaching and Teacher Education, 13(7), 665-674. https://doi.org/10.1016/s0742-051x(97)00014-0

Denzin, N. K. (1999). Biographical research methods. Í J. P. Keeves, og G. Lakomski (ritstjórar), Issues in educational research (bls. 92-102). Amsterdam: Elsevier. 
Diamond, C. T. P. (1991) Teacher education as transformation: A psychological perspective. Milton Keynes: Open University Press.

Dwyer, R., Davis. I. og Emerald, E. (ritstjórar). (2017). Narrative research in practice: Stories from the field. Singapore: Springer.

Elbaz, F. (1990). Knowledge and discourse: The evolution of research on teacher thinking. Í C. Day, M. Pope og P. Denicolo (ritstjórar), Insight into teachers' thinking and practice (bls. 15-42). London: Falmer Press.

Fantilli, R. D og McDougall, D. E. (2009). A study of novice teachers: Challenges and supports in the first years. Teaching and Teacher Education, 25(6), 814-825. https:// doi.org/10.1016/j.tate.2009.02.021

Goodson, I. F. (1981). Life histories and the study of schooling. Interchange, 11(4), 62-76.

Goodson, I. F. (1992a). Studying teachers' lives: An emergent field of inquiry. Í I. F. Goodson (ritstjóri), Studying teachers' lives (bls. 1-17). London: Routledge.

Goodson, I. F. (1992b) Studying teachers' lives: Problems and possibilities. Í I. F. Goodson (ritstjóri), Studying teachers' lives (bls. 234-249). London: Routledge.

Hafdís Ingvarsdóttir. (2013). Lífssaga sem rannsóknarađferđ. í Sigríđur Halldórsdóttir (ritstjóri), Handbók í ađferđafræđi rannsókna (bls. 337-345). Akureyri: Háskólinn á Akureyri.

Hafdís Ingvarsdóttir. (2014). Reflection and work context in teacher learning: Two case studies from Iceland. Í C. H. Craig og L. Orland-Barak (ritstjórar), International teacher education: Promising pedagogies (Part A, bls. 91-112). Bingley: Emerald.

Hafdís Ingvarsdóttir. (2018). Kennsluhættir speglađir í ljósi sjálfræđis: Virđing, ábyrgð og traust. Netla - Veftímarit um uppeldi og menntun, Sérrit 2018 - Framhaldskólinn í brennidepli. Sótt af http://netla.hi.is/serrit/2018/framhaldskolinn_brennidepli/03.pdf

Hargreaves, A. og Fullan, M. (2012). Professional capital: Transforming teaching in every school. New York: Teachers College Press.

Hildur Hauksdóttir, María Steingrímsdóttir og Birna María B. Svanbjörnsdóttir. (2018). Mótun starfskenningar nýrra framhaldsskólakennara: Hvađa pættir ráđa för? Tímarit um uppeldi og menntun, 27(2), 135-154. https://doi.org/10.24270/tuuom.2018.27.7

Kagan, D. (1992). Professional growth among preservice and beginning teachers. Review of Educational Research, 6(2), 129-169. https://doi.org/10.3102/00346543062002129

Kelchtermans, G. (1993). Getting the story, understanding the lives: From career stories to teachers' professional development. Teaching and Teacher Education, 9(5-6), 443456. https://doi.org/10.1016/0742-051x(93)90029-g

Kelly, G. A. (1955). The psychology of personal constructs (1. og 2. bindi). London: Norton. Knowles, J. G. (2001). Exploring method. Í A. L. Cole og J. G. Knowles (ritstjórar), Lives in context: The art of life history research (bls. 9-128). Lanham: AltaMira Press.

Lave, J. og Wenger, E. (1991). Situated learning: Legitimate peripheral participation. Cambridge: Cambridge University Press.

Louchran, J. (1996). Learning about teaching: A longitudinal study of beginning teachers.

The Australian Educational Researcher, 23(2), 55-77. https://doi.org/10.1007/ bf03219620

Measor, L. og Sikes, P. (1992). Visiting lives: Ethics and methodology in life history. Í I. F. Goodson (ritstjóri), Studying teachers' lives (bls. 209-233). London: Routledge. 
Pope, M. og Denicolo, P. (1993) The art and science of constructive research in teacher thinking. Teaching and Teacher Education, 9(5-6), 529-544. https://doi.org/10.1016/ 0742-051x(93)90036-g

Pope, M. og Denicolo, P. (2001) Transformative education: Personal construct approaches to practice and research. London: Whurr.

Shulman L. S. (1986). Those who understand: Knowledge growth in teaching. Educational Researcher, 15(2), 4-14. https://doi.org/10.2307/1175860

Shulman, L. S. (1987). Knowledge and teaching: Foundations of the new reform. Harvard Educational Review, 57(1), 1-23. https://doi.org/10.17763/haer.57.1.j463w7 9r56455411

Sigrún Ađalbjarnardóttir. (2007). Virđing og umhyggja: Ákall 21. aldar. Reykjavík: Heimskringla, háskólaforlag Máls og menningar.

Tierney, W. G. (2000). Undaunted courage: Life history and the postmodern challenge. Í N. K. Denzin, Y. S. Lincoln (ritstjórar), Handbook of qualitative research (2. útgáfa, bls. 537-553). Thousand Oaks: SAGE.

West, L. Alheit, P., Anderson A. S. og Merrill, B. (ritstjórar). (2007). Using biographical and life history approaches in the study of adult and lifelong learning: European perspectives (2. bindi). Frankfurt am Main: Peter Lang.

Worthy, J. (2005). 'It didn't have to be so hard': The first years of teaching in an urban school. International Journal of Qualitative Studies in Education, 18(3), bls. 379-398. https://doi.org/10.1080/09518390500082699

Zeichner, K.M., Tabaschnick, B. R. og Densmore, K. (1987). Individual, institutional and cultural influences on the development of teachers' craft knowledge. Í J. Calderhead (ritstjóri), Exploring teachers' thinking (bls 21-59). London: Cassell.

Greinin barst tímaritinu 5. júní 2019 og var sampykkt til birtingar 2. nóvember 2019

\section{UM HÖFUNDINN}

Hafdís Ingvarsdóttir (hei@hi.is) er prófessor emeritus. Hún lauk B.A.-prófi frá Háskóla Íslands og stundađi framhaldsnám við Kaupmannahafnarháskóla. Hún er međ meistaragráđu í kennslufræđi frá Háskólanum í Reading í Englandi međ áherslu á tungumálanám og kennslu og doktorspróf í menntunarfræđi frá sama skóla. Rannsóknir hennar hafa einkum beinst að kennsluháttum í framhaldsskólum, starfskenningum kennara og starfsproska peirra. Hún hefur einnig stundađ rannsóknir á sviđi tungumálanáms og -kennslu og hefur nýlokið langtímarannsókn á stöđu ensku á Íslandi (ásamt Birnu Arnbjörnsdóttur) en niðurstöður hennar birtust í bókinni Language Development across the Life Span. 


\section{Understanding the world of others is a challenge: Exploring teacher thinking}

\section{ABSTRACT}

The purpose of this paper is to present and describe approaches aimed at gaining access to teacher thinking, their attitudes and beliefs about their complex profession. The paper starts by reporting the development of teacher research in the past century. In the final decades of the 20th century a new ideology emerged in researching teachers and teaching (Goodson 1992a; Shulman, 1987). This kind of research is based on constructivist philosophy. Its main aim is to understand teachers and to gain a deeper understanding of their attitudes and beliefs about teaching. New concepts were developed to describe teachers' thought processes: cognitions, beliefs, personal theories, personal practical knowledge, and subjective theories to name but a few. Teachers' personal theories are based on moral values and they comprise both an intellectual and emotional dimension (Pope \& Denicolo, 2001). Accordingly, the key to gaining insight into and understanding teachers' personal theories, is to listen and give voice to teachers (Elbaz, 1990). Although previous research methods, named the process-product research, which mainly focused on teachers' observable behaviour, were important and yielded significant knowledge about teaching, a new approach was called for to obtain a more qualitative knowledge. The aim was to gain knowledge on how teachers reason about their multifaceted work. Teachers were now seen as agents of their own professional growth. For this purpose, various approaches, methods and techniques have been developed over the past decades. One important issue is that we no longer talk about research on or about teachers but research in cooperation with teachers. Teachers are not seen as research objects but as co-workers where both partners are looking for a more comprehensive and deeper understanding of the individual teacher's thinking. To get even closer to the core of teachers' personal theories it has been found fruitful to elicit what it is in the lives of teachers, their milieu and work, which they perceive as being influential in forming their theories and embedded values. This interest in investigating teachers' life history reflects a radical turn in our understanding of teaching. To obtain this kind of data, four methods are demonstrated in detail in this paper: classroom observation, river of life, life history, and a self-characterization sketch. To better understand how these approaches can be implemented, the life history of one teacher is exemplified in depth in this paper. His professional life is reported and he describes how he has grown as a teacher over the years. His life history illustrates how his personal theories have developed, both in depth and breadth. The case study starts with classroom observations where Ingi, a secondary school teacher, is teaching English to many classes of diverse proficiency. Subsequently Ingi draws up his river of life and the following life history he shares with the researcher is based on his river of life. To eliminate the researcher's influence on the story as far as possible no beforehand written questioning is used. Lastly, Ingi writes his self-characterization sketch. It is important to be aware that this kind of research makes high moral 
demands on the researcher; sensitivity and caution are essential. It should be emphasised that as the researcher and the storyteller are co-workers, the story cannot be published without the story teller's consent. To conclude, it should be pointed out that although teachers and their professionalism are the focus of this research, these methods can and have been implemented to understand and give voice to other professionals.

Keywords: teacher research, life history research, the development of personal theories

\section{ABOUT THE AUTHOR}

Hafdis Ingvarsdottir (hei@hi.is) is professor emeritus. She graduated with a B.A. degree from the University of Iceland followed by postgraduate studies at the University of Copenhagen. Hafdís holds a master's degree in teaching and instruction with emphasis on modern languages from the University of Reading, UK, and a Ph.D. in education from the same university. Her research mainly focuses on teaching practices in the upper secondary school, teacher cognitions, teacher development, language teaching and learning. Her most recent publication is the book Language Development across the Life Span reporting a longitudinal study on the status of English in Iceland (with Birna Arnbjörnsdóttir). 